\title{
Serum $\mathrm{Lp}$ (a) lipoprotein concentration and outcome of thrombolytic treatment for myocardial infarction
}

Anthony D MBewu, Paul N Durrington, Michael I Mackness, Linda Hunt, Wajdi H Turkie, John E Creamer

\begin{abstract}
Background-Lp(a) lipoprotein has structural homology with plasminogen and has been shown to inhibit plasminogen activation in vitro.

Objective-To determine whether the serum concentration of $\mathbf{L p}$ (a) lipoprotein present when streptokinase was given in acute myocardial infarction influenced the outcome as judged by electrocardiographic methods.
\end{abstract}

Patients and design-Serum Lp(a) lipoprotein concentration was measured in 135 consecutive patients admitted with a diagnosis of acute myocardial infarction who received streptokinase treatment. Recovery from myocardial injury was assessed by the reduction in the sum of ST segment elevation measured from the J point (STJ) in the electrocardiogram immediately before streptokinase was given compared with that three hours later.

Results-The serum Lp(a) lipoprotein concentrations were measured within 12 hours of the onset of symptoms of myocardial infarction and were higher than in healthy reference populations. Recovery from myocardial infarction could be assessed from the STJ in 116 patients ( $86 \%$ of the series). Those in whom it could not had bundle branch block, left ventricular hypertrophy, did not survive three hours, or had started intravenous nitrate treatment or some other clinical procedure before or at the time the second electrocardiogram was to be recorded. Patients with reductions in STJ after streptokinase that were $>4$ mm (the median decrease) had mean (range) serum Lp(a) lipoprotein concentrations of $41.0(0 \cdot 8-220) \mathrm{mg} / \mathrm{dl}$ and those with a smaller reduction in STJ had concentrations of $29 \cdot 1(1 \cdot 7-151) \mathrm{mg} / \mathrm{dl}$. The difference was not statistically significant.

Conclusion-In this study $\mathbf{L p ( a ) ~ l i p o p r o -}$ tein concentration did not significantly influence the outcome of thrombolytic treatment with streptokinase.

(Br Heart f 1994;71:316-321)

Thrombolysis is well established in the treatment of myocardial infarction ${ }^{1-3}$ and has been shown to increase patency of the infarct related coronary artery, ${ }^{4}$ reduce the size of the myocardial infarct, ${ }^{5}$ preserve left ventricular dimensions and function, ${ }^{67}$ and reduce both early and late mortality. ${ }^{89}$

The $\mathrm{Lp}$ (a) lipoprotein is widely held to be an important risk factor in coronary heart disease. High serum $\mathrm{Lp}$ (a) lipoprotein concentrations are associated with an increased prevalence of angina pectoris, myocardial infarction, and coronary artery disease assessed angiographically. ${ }^{10-12}$ The $\operatorname{Lp}(a)$ lipoprotein has close structural homology with plasminogen ${ }^{13}$ and can impede fibrinolysis at the surface of cultured human endothelial cells. ${ }^{14}$ Enormous doses of thrombolytic agent are used in the treatment of myocardial infarction, however, which might be predicted from in vitro studies, to overwhelm any competition by $\operatorname{Lp}(a)$ lipoprotein. ${ }^{15}$ None the less in vivo similar kinetic considerations may not apply locally at a thrombosis in a coronary artery and the possibility remains that $\mathrm{Lp}(\mathrm{a})$ lipoprotein might impede plasminogen activation or compete with plasminogen and plasmin treatment impeding breakdown of the fibrin clot.

We therefore investigated the influence of the prevailing serum concentration of $L p(a)$ lipoprotein on the clinical outcome of acute myocardial infarction treated with streptokinase.

\section{Patients and methods}

PATIENTS

Approval for this study was obtained from the Clinical Ethics Committee of our hospital, and all patients participating gave their informed consent. All patients admitted to the coronary care unit with a diagnosis of acute myocardial infarction were treated with streptokinase unless there were specific contraindications-namely, more than 12 hours since the onset of continuous chest pain; confirmed peptic ulcer within the previous six months; current symptoms suggestive of peptic ulcer; cerebrovascular accident within the past 12 months; bleeding diathesis; recent surgery (less than three months); streptokinase treatment within the past six months.

Between September 1989 and February 1991162 consecutive patients were admitted to our coronary care unit with a diagnosis of definite myocardial infarction and no contraindication to streptokinase. Two died immediately leaving 160 who were treated with intravenous streptokinase (1.5 MU over one hour, Hoechst Streptase or Kabi Vitrum Kabikinase). Venous blood was taken

University of
Manchester
Department of
Cardiology
A D MBewu
W H Turkie
J E Creamer
University of
Manchester
Department of
Medicine
P N Durrington
M I Mackness
University of
Manchester Faculty of
Medicine
Computational
Group, Manchester
Royal Infirmary
Linda Hunt
Correspondence to:
Dr Paul N Durrington,
The University Department
of Medicine Manchester
Royal Infirmary, Oxford
Road, Manchester M13
9WL.
Accepted for publication
1 November 1993.


immediately before the infusion of streptokinase for the determination of serum $\mathrm{Lp}(\mathrm{a})$ lipoprotein and plasma fibrinogen. Serum $\mathrm{Lp}$ (a) lipoprotein values before streptokinase were obtained for 135 patients (eight declined to participate, and in 17 cases no satisfactory sample was obtained for measurement generally because the clinical team on duty started the streptokinase infusion before obtaining blood for the study or because of clinical urgency). In a subset of patients serum $\mathrm{Lp}(\mathrm{a})$ lipoprotein and fibrinogen were also measured at the end of the streptokinase infusion. We include the fibrinogen results. There was no change in serum $\mathrm{Lp}$ (a) lipoprotein concentrations after the infusion of streptokinase. ${ }^{16}$

Twelve weeks after the myocardial infarction, patients were seen in our clinic by $\mathrm{ADM}$ to check for recurrent angina, heart failure, changes in medication, blood pressure, weight, and height. On this occasion a fasting blood sample was obtained after the patient had fasted since 2200 the previous night. The serum cholesterol, triglyceride, high density lipoprotein cholesterol, and apolipoprotein B results presented here were obtained from this sample. In a subset of patients it was shown that these values were not significantly different from those obtained on admission. ${ }^{16}$ Seventeen $(12.6 \%)$ of the 135 patients with $\mathrm{Lp}$ (a) lipoprotein values before streptokinase had died by the time of the 12 week visit. Data for some variables are incomplete for this reason.

\section{CARDIOLOGICAL INVESTIGATION}

The diagnosis of myocardial infarction was based on a history of typical, prolonged ( $>30$ minutes) chest pain, plus diagnostic electrocardiographic changes of $\geqslant 2 \mathrm{~mm}$ of ST segment elevation in at least two contiguous precordial leads on the admission electrocardiogram or $\geqslant 1 \mathrm{~mm}$ of ST elevation in two or more inferior electrocardiographic leads, plus a diagnostic rise in serum cardiac enzymes.

The electrocardiogram on admission to hospital was taken by trained nurses in the casualty department or coronary care unit and venous blood was taken at that time for estimation of serum $\mathrm{Lp}(\mathrm{a})$ lipoprotein. Streptokinase was given as soon as possible once the diagnosis was made and the patient was given aspirin $(150 \mathrm{mg})$ to chew (provided there was no history of allergy to aspirin). No patients had an allergy to aspirin but 10 of the $153(6.5 \%)$ patients did not receive aspirin because of a history of peptic ulcer or dyspepsia.

A second electrocardiogram was performed three hours after starting streptokinase. This was compared with the electrocardiogram recorded immediately before the streptokinase. Changes in the sum of ST elevation in all 12 leads of the electrocardiogram at the J point (STJ) and $60 \mathrm{~ms}$ after the J point were measured. Changes in the degree of ST elevation in the lead with the maximum ST elevation (STmax) at the start of streptokinase infusion were also measured. The decline in the sum of ST elevation in the electrocardio- gram has previously been shown to correlate well with recovery from myocardial injury and reperfusion of the infarct-related artery. ${ }^{17-19} \mathrm{Of}$ the 135 patients studied 116 had electrocardiograms that could be analysed. Six could not because of left or right bundle branch block or left ventricular hypertrophy, four could not because the patients died before the second electrocardiogram, and nine were excluded because intravenous nitrate infusion had been given to the patients in the interval between the first and second electrocardiogram or the second electrocardiogram could not be recorded at three hours because the patient's condition demanded some other more urgent clinical procedure at the time.

Electrocardiograms were performed daily during the 48 hour or longer stay on the coronary care unit and again before discharge from hospital, and the clinical progress of the patient was monitored by one of us. The electrocardiogram recorded before discharge from hospital was used to calculate a Selvester score, which correlates well with the size of the myocardial infarction. ${ }^{2021}$

Sixty five of the patients had coronary angiography at a median of six days after thrombolysis, and these films were used to check for patency of the infarct related artery with a protocol from the Thrombolysis in Myocardial Infarction Study. ${ }^{4}$ Coronary angiography was performed in all patients under the age of 50 for men and 65 for women $(n=24)$ and in patients with recurrent chest pain after myocardial infarction $(n=39)$, or for other clinical indications $(n=2)$, unless there were contraindications such as massive myocardial infarction with poor ensuing left ventricular function.

The films were independently scrutinised by two experienced angiographers on different occasions to assess the patency of the infarct related artery. ${ }^{4}$ Both observers were unaware of the clinical state or blood results of the patients.

\section{LABORATORY METHODS}

High density lipoprotein cholesterol was measured by the managanese/heparin precipitation method. ${ }^{22}$ Serum total cholesterol was determined enzymatically (reagent supplied by Diamed, Murten, Switzerland) and serum triglycerides by the glyceryl phosphate oxidase-peroxidase-aminophenazone method (Boehringer Mannheim, Mannheim, Germany). Within batch coefficients of variation for cholesterol and triglyceride assays were $1.5 \%$ and $2 \cdot 1 \%$ respectively. Our laboratory participates in the national quality control scheme. Apolipoprotein B was determined by immunonephelometry with the Beckman Array (Beckman Instruments, Palo Alto, California, USA). The antiserum to apolipoprotein B was supplied by Beckman. The method was repeatedly calibrated against a secondary serum standard, the apolipoprotein B concentration of which was determined by immunoelectrophoresis with a primary standard of lipoprotein of density 1.040 $1.053 \mathrm{~g} / \mathrm{ml}$ isolated by ultracentrifugation. ${ }^{22}$ 
Table 1 Characteristics of patients on admission to the coronary care unit (mean (SD)) or median (range))

\begin{tabular}{lccc}
\hline & All patients & $\begin{array}{l}\text { Patients whose } S T \\
\text { change could be } \\
\text { measured }\end{array}$ & $\begin{array}{l}\text { Patients with } \\
\text { coronary } \\
\text { angiograms }\end{array}$ \\
\hline No (M:F) & $135(106: 29)$ & $116(91: 25)$ & $62(53: 9)$ \\
Age (y) & $58(32-82)$ & $59(32-82)$ & $54(34-71)$ \\
Serum cholesterol (mmol/l) & $6 \cdot 81(1 \cdot 52)$ & $6 \cdot 74(1 \cdot 54)$ & $6 \cdot 84(1 \cdot 52)$ \\
Serum triglycerides (mmol//) & $2 \cdot 23(0 \cdot 61-8 \cdot 64)$ & $2 \cdot 22(0 \cdot 61-8 \cdot 64)$ & $2 \cdot 25(0 \cdot 90-8 \cdot 17)$ \\
Serum HDL cholesterol (mmol/1) & $0 \cdot 9(0 \cdot 35)$ & $0 \cdot 91(0 \cdot 35)$ & $0 \cdot 91(0 \cdot 40)$ \\
Serum apolipoprotein B (mg/dl) & $113(31)$ & $111(31)$ & $113(32)$ \\
Serum Lp(a) lipoprotein (mg/dl) & $34 \cdot 0(0 \cdot 8-220 \cdot 0)$ & $34 \cdot 7(0 \cdot 8-220 \cdot 0)$ & $24 \cdot 2(0 \cdot 8-184 \cdot 8)$ \\
Plasma fibrinogen (g/l) & $3 \cdot 26(1 \cdot 11)$ & $3 \cdot 26(1 \cdot 12)$ & $3 \cdot 29(0 \cdot 94)$ \\
Smokers (\%) & 60 & 58 & 64 \\
Previous MI (\%) & 18 & 18 & 18 \\
Systolic BP (mm Hg) & $140(33)$ & $141(34)$ & $136(26)$ \\
Diastolic BP (mm Hg) & $86(21)$ & $86(21)$ & $87(16)$ \\
Quetelet's index (Kg/m & $26 \cdot 1(3 \cdot 9)$ & $25 \cdot 9(3 \cdot 8)$ & $26 \cdot 9(3 \cdot 9)$ \\
\hline
\end{tabular}

Complete data were available for $L p(a)$ lipoprotein and for $>85 \%$ of patients for other variables except HDL (76\%), apolipoprotein B (73\%), fibrinogen (53\%), and Quelelet's index $(80 \%)$. HDL, high density lipoprotein, MI, myocardial infarction.

The $\mathrm{Lp}$ (a) lipoprotein was determined by a two site immunoradiometric assay (Pharmacia, Uppsala, Sweden) previously evaluated in this laboratory. ${ }^{10}$ This method shows no cross immunoreactivity with plasminogen or with low density lipoprotein, and has a lower detection limit of $0.06 \mathrm{mg} / \mathrm{dl}$. The method was calibrated in our laboratory against the standard provided by Pharmacia. The results were expressed as $\mathrm{mg}$ total protein in $\mathrm{Lp}(\mathrm{a})$ lipoprotein (apolipoprotein(a) and apolipoprotein B) per $\mathrm{dl}$ serum, after repeated comparisons of the results obtained with the standard and preparations of $\mathrm{Lp}(\mathrm{a})$ lipoprotein isolated from pooled serum by ultracentrifugation and affinity chromatography. The protein concentration of these was determined by a modification of the Lowry method. The within batch coefficients of variation for the apolipoprotein $\mathrm{B}$ and $\mathrm{Lp}(\mathrm{a})$ lipoprotein assays were $5 \cdot 4 \%$ and $2 \cdot 1 \%$ respectively. In all lipid and apolipoprotein assays quality control serum samples were included to ensure that between batch variation was within acceptable limits. Serum creatine kinase activity was measured in the routine clinical chemistry laboratory for three days after admission.

\section{STATISTICS}

The unpaired Student's $t$ test was used to compare the means of the variables, which were normally distributed. Serum $\mathrm{Lp}(\mathrm{a})$ lipoprotein concentrations and coronary

Table 2 Serum Lp(a) lipoprotein concentrations (median (range)) in patients above and below median change in ST segment elevation over the three hours after the intravenous infusion of streptokinase

\begin{tabular}{|c|c|c|c|}
\hline $\begin{array}{l}\text { Change in ST segment } \\
\text { elevation }\end{array}$ & No & $\begin{array}{l}\text { Serum } L p(a) \text { lipoprotein } \\
(m g / d l)\end{array}$ & $p$ value ${ }^{*}$ \\
\hline $\begin{array}{l}\text { J point: } \\
<4 \mathrm{~mm}\end{array}$ & 56 & $29 \cdot 1(1 \cdot 7-151)$ & \multirow{2}{*}{0.087} \\
\hline $\begin{array}{l}\geqslant 4 \mathrm{~mm} \\
60 \mathrm{~ms}: \\
<4 \mathrm{~mm}\end{array}$ & 60 & $\begin{array}{l}41 \cdot 0(0 \cdot 8-220) \\
28 \cdot 8(1 \cdot 7-215)\end{array}$ & \\
\hline$\underset{\text { ST max: }}{\geqslant 4 \mathrm{~mm}}$ & 59 & $39.9(0.8-220)$ & 0.089 \\
\hline$<1.5 \mathrm{~mm}$ & 48 & $26 \cdot 8(1 \cdot 7-151)$ & \multirow[t]{2}{*}{0.083} \\
\hline$\geqslant 1.5 \mathrm{~mm}$ & 68 & $41 \cdot 0(0 \cdot 8-220)$ & \\
\hline
\end{tabular}

^Mann-Whitney test (two tailed) artery disease (Selvester) scores were compared with the non-parametric MannWhitney U test. Qualitative variables with two categories (sex, number with previous myocardial infarction, family history of coronary heart disease, smokers, proportion of patients with occluded infarct related artery who have serum $\mathrm{Lp}(\mathrm{a})$ lipoprotein $>25$ $\mathrm{mg} / \mathrm{dl}$, percentage of patients with serum $\mathrm{Lp}$ (a) lipoprotein greater or less than the median $L p(a)$ lipoprotein, and percentage of patients with STJ greater or less than the median STJ) were compared with the $2 \times 2 \chi^{2}$ test or Fisher's exact test (if the numbers were small).

Correlations between variables were sought with Kendall's test. The Wilcoxon matched pairs test was used to compare $\mathrm{Lp}$ (a) lipoprotein before myocardial infarction and at 12 weeks after myocardial infarction. Two tailed tests are reported throughout.

\section{Results}

PATIENTS STUDIED

Table 1 shows the clinical characteristics of the patients. The patients tended to have high cholesterol and triglycerides and low high density lipoprotein cholesterol compared with typical values for a healthy British population. The serum $\mathrm{Lp}$ (a) lipoprotein values were high, the median value in healthy local people being $10 \mathrm{mg} / \mathrm{dl}^{23}$ The site of the myocardial infarction on electrocardiographic criteria was inferior in $48 \%$, anterior in $45 \%$, posterior in $4 \%$, and lateral in $3 \%$. The median (range) time between the onset of chest pain and the start of the intravenous infusion of streptokinase was three $(0 \cdot 5-14)$ hours.

\section{MORTALITY}

Seventeen $(12.6 \%)$ of the 135 patients investigated died during the next three months. The median (range) serum $\mathrm{Lp}$ (a) lipoprotein concentration immediately before streptokinase in those who died was $28.8(1 \cdot 7-85 \cdot 0) \mathrm{mg} / \mathrm{dl}$, which was not significantly different from those who survived $(34 \cdot 0(0 \cdot 8-220 \cdot 0) \mathrm{mg} / \mathrm{dl})$. There was no significant relation between serum $\mathrm{Lp}$ (a) lipoprotein concentrations and mortality within the first three months or heart failure treated within the first three days.

ELECTROCARDIOGRAPHIC INDICES OF OUTCOME OF THROMBOLYTIC TREATMENT When patients whose ST segment recovery exceeded the median rate were compared with those with rates below this value (table 2) there was a tendency for serum $\mathrm{Lp}$ (a) lipoprotein concentrations to be higher in patients whose ST segments returned rapidly towards the isoelectric line than in those in whom it was slower to return. This was so regardless of the measure of ST segment elevation used. The difference was not significant by two tailed tests, which we considered should be used because our original hypothesis was that high circulating $\mathrm{Lp}(\mathrm{a})$ lipoprotein at the time of streptokinase infusion might unfavourably affect its outcome. 
Table 3 Characteristics of the 62 patients who had coronary angiography mean (SD)) or median (range))

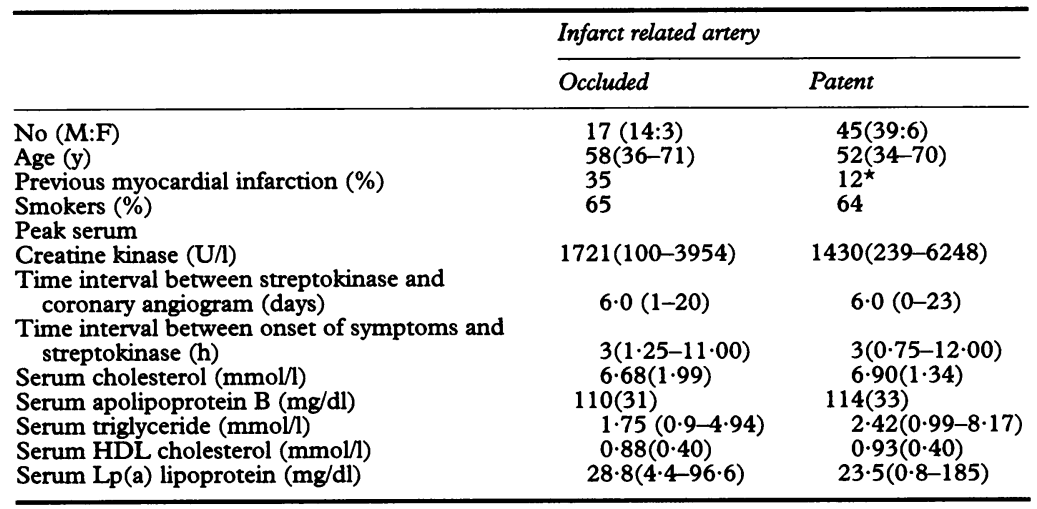

${ }^{\star} \mathrm{p}=0.085$. All differences are NS. Data are incomplete for cholesterol, triglycerides, high density lipoproteins, and apolipoprotein B, because some patients did not survive until 12 weeks (see methods). infarction were available for 84 patients. Median serum $\mathrm{Lp}$ (a) lipoprotein 12 weeks after myocardial infarction was $42 \cdot 4$ $(0 \cdot 8-210) \mathrm{mg} / \mathrm{dl}$ and before streptokinase was $30 \cdot 2(0 \cdot 8-220) \mathrm{mg} / \mathrm{dl}$. These values were of borderline significance $(p=0.053)$.

\section{Discussion}

There is an enormous volume of case-control evidence linking serum $\mathrm{Lp}(\mathrm{a})$ lipoprotein concentrations and premature coronary heart disease. ${ }^{10-12}$ Furthermore in European populations a parental history of coronary heart disease early in life is associated with increased serum $\mathrm{Lp}$ (a) lipoprotein concentrations in offspring. ${ }^{124}$ Also in familial hypercholesterolaemia, in which risk of coronary heart disease is greatly increased, the serum $\mathrm{Lp}$ (a) lipoprotein concentration is raised. ${ }^{2325}$ Prospective studies are, however, less persuasive with on $^{26}$ supporting $\mathrm{Lp}$ (a) lipoprotein as a determinant of risk of coronary heart disease and two failing to do so. ${ }^{27} 28$ In our investigation the median $\mathrm{Lp}$ (a) lipoprotein value within 12 hours of the onset of symptoms of acute myocardial infarction was more than three times that of a healthy British population..$^{23} \mathrm{It}$ is likely that the $\operatorname{Lp}(a)$ lipoprotein value this early in the course of myocardial infarction reflected its premorbid concentration and our study thus supports the view that $L p(a)$ lipoprotein is predictive of myocardial infarction. There was a tendency for serum $\mathrm{Lp}(\mathrm{a})$ lipoprotein concentrations to be higher 12 weeks after myocardial infarction than immediately after it. Maeda and colleagues found no acute changes in serum $\mathrm{Lp}(\mathrm{a})$ lipoprotein concentrations in the week after myocardial infarction, but there was a rise in some patients during the second week. ${ }^{29}$ In a study of similar design we confirmed the relative stability of serum $\mathrm{Lp}(\mathrm{a})$ lipoprotein in the week after myocardial infarction with greater variation in the concentrations in the second week. ${ }^{16}$ It is thus possible that the increase at 12 weeks after myocardial infarction may reflect this late rise in some people.

The $\mathrm{Lp}$ (a) lipoprotein is distinguished from other lipoproteins by possessing an apolipoprotein, apolipoprotein(a), which is a mutation of plasminogen. It has a protease domain structurally similar to that of plasminogen, but is not activated to lyse fibrin by plasminogen activators. Furthermore in place of the short series of five kringles present in plasminogen, $\operatorname{Lp}(\mathrm{a})$ lipoprotein has a long series of kringles due to repetition of kringles homologous to the fourth kringle of plasminogen. The number of these repeats is determined by a single genetic locus and is responsible both for the genetic variation in the molecular mass of apolipoprotein(a) and largely for its circulating concentration. ${ }^{30}$

Because of its resemblance to plasminogen and its lack of activation by known plasminogen activating factors, $\mathrm{Lp}(\mathrm{a})$ lipoprotein seems an obvious candidate to inhibit fibrinolysis competitively. There are in vitro studies that show that it will bind to plasminogen
CONCENTRATION AFTER MYOCARDIAL

INFARCTION

Paired serum samples taken before streptokinase infusion and 12 weeks after myocardial 
receptors $^{31}$ and to fibrin ${ }^{32}$ and that it will inhibit plasminogen activation. ${ }^{14}$ One attempt to show that $\mathrm{Lp}(\mathrm{a})$ lipoprotein does bind to plasminogen receptors in vivo, however, proved negative. ${ }^{33}$ There have been three previous studies in which in vivo evidence of an effect of $\mathrm{Lp}$ (a) lipoprotein on thrombolysis has been sought with the clinical outcome of patients undergoing thrombolytic treatment for acute myocardial infarction as the model. ${ }^{34-36}$ In none of these reports was streptokinase used. Nor was the electrocardiographic response investigated. These studies were small, involving only $20-50$ patients, and because coronary angiography could not be undertaken without a clinical indication (as in our present study) they may have been confounded by selection bias. The results of these studies, like ours, showed no effect of $L p(a)$ lipoprotein on the patency of infarct-related coronary arteries.

We considered that the electrocardiographic response to thrombolytic treatment might provide an insight into the in vivo effect of $\mathrm{Lp}(\mathrm{a})$ lipoprotein in a larger, less biased series of patients than was possible with coronary angiography. This proved to be the case because it was possible to assess the rate of recovery of the ST segment elevation in $86 \%$ of a series of 135 patients. (The remainder could not be assessed as their electrocardiograms were unsuitable and showed abnormalities such as left bundle branch block and left ventricular hypertrophy). One factor limiting the return of the ST segment to the isoelectric line when thrombolytic treatment has been given is whether the ischaemic myocardium is successfully reperfused. ${ }^{19}$ We therefore reasoned that were $\mathrm{Lp}$ (a) lipoprotein to interfere with thrombolysis a greater proportion of patients with high concentrations of serum $\mathrm{Lp}$ (a) lipoprotein at the time they received streptokinase would show a slower recovery in ST segment elevation. We found no evidence for this possibility in our study. Indeed, the patients with the more rapid decline of ST segments had a median concentration of $\mathrm{Lp}$ (a) lipoprotein that was one third greater than that of those with a slower response. This trend was close to significance and would have been so had our original hypothesis been that $\mathrm{Lp}$ (a) lipoprotein may have conferred some benefit. It is thus important to consider alternative hypotheses that might explain the results. One suggestion is that the coronary thrombosis, which forms in patients with high circulating $\mathrm{Lp}(\mathrm{a})$ lipoprotein concentrations, is particularly susceptible to lysis by streptokinase and thus reperfusion is more often evident in such patients. This may not be as improbable as it at first seems because Mao et al reported enhanced fibrinolysis in the presence of high $\mathrm{Lp}(\mathrm{a})$ lipoprotein concentrations in vitro. ${ }^{37}$ This possibility is, however, not supported by the angiographic part of our study or the results of others. ${ }^{34-36}$

A second hypothesis to explain our electrocardiographic findings might be that they result, not so much from greater reperfusion of the myocardium in the patients with high serum $\mathrm{Lp}$ (a) lipoprotein concentrations, but that they represent a greater degree of reperfusion injury in patients with low serum $\mathrm{Lp}(\mathrm{a})$ lipoprotein concentrations. If this were the case, its explanation might be that $\operatorname{Lp}(a)$ lipoprotein was acting to limit the extent of bleeding into the perinfarction zone after dissolution of the clot. Such bleeding leads to the morbid anatomical appearance of "red infarction" 38 and has been implicated as the cause of reperfusion injury (associated with prolonged elevation of ST segments due to persisting "current-of-injury"), slower recovery from myocardial injury, and eventually impaired ventricular remodelling. ${ }^{3940}$ Both coronary thrombolysis and red infarction can occur spontaneously during myocardial infarction, although they are more likely to do so if a thrombolytic agent has been given.

Thus although $\mathrm{Lp}$ (a) lipoprotein may be related to the risk of developing coronary atheroma, our findings do not exclude a possible beneficial effect during myocardial infarction. This suggests caution in the use of treatments aimed at lowering serum $\mathrm{Lp}(\mathrm{a})$ lipoprotein concentrations in patients at risk of coronary heart disease, because there may be advantages as well as disadvantages from a high concentration of circulating $\mathrm{Lp}(\mathrm{a})$ lipoprotein. Any in vivo effects it might have on coagulation are difficult to predict from in vitro experiments. We believe that serum $\mathrm{Lp}$ (a) lipoprotein concentrations should be correlated with the clinical outcome in larger trials of thrombolytic treatment.

This study was supported by an infrastructure award to PND and a Research Fellowship to ADM from the Northwest Regional Health Authority. We are grateful to the nurses and doctors of the casualty department and the coronary care unit of the Manchester Royal Infirmary for their contribution to this work and our consultant cardiology colleagues Drs DJ work and our consultant cardiology colleagues Drs DJ
Rowlands, LC, Cotter, G Howitt and all the general physiRowlands, LC, Cotter, G Howitt and all the general physi-
cians at the Royal Infirmary who allowed us to study patients under their care. We are indebted to Miss S Arrol for technical under their care. We are indebted to Miss S Arrol for technical
assistance and to Miss C Price for expertly typing the paper.

1 GISSI Study Group. Effectiveness of intravenous thrombolytic treatment in acute myocardial infarction. Lancet 1986;i:397-401.

2 ISIS 2 (Second International Study of Infarct Survival Collaborative Group). Randomised trial of intravenous streptokinase, oral aspirin, both or neither among 17187 cases of suspected myocardial infarction. Lancet 1988;ii: 349-60.

3 Wilcox RG, Von der Lippe G, Olson CG, Jensen G, Skene $A M$, Hampton JR. Trial of tissue plasminogen activator for mortality reduction in acute myocardial infarction. Lancet 1988;ii:525-30.

4 Chesebro JH, Knatterud G, Roberts R, Borer J, Cohen LS, Dalen J, et al. Thrombolysis in myocardial infarction (TIMI) trial, phase 1: a comparison between intravenous tissue plasminogen activator and

5 Van der Werf F, Arnold AER. For the European Cooperative Study Group for recombinant tissue type Cooperative Study Group for recombinant tissue type
plasminogen activator. Intravenous tissue plasminogen plasminogen activator. Intravenous tissue plasminogen activator and the size of infarcts, left ventricular function and survival in act

6 Marino P, Zanolla L, Zardini P. On behalf of the Gruppo Italiano per lo Studio della Streptochinasi nell Infarto Miocardico (GISSI). Effect of streptokinase on left ventricular modelling and function after myocardial infarction. $\mathcal{F}$ Am Coll Cardiol 1989;14:1149-58.

7 White HD, Norris RM, Brown MA, Takayama M Maslowski A, Bass HM, et al. Effect of intravenous streptokinase on left ventricular function and early survival after acute myocardial infarction. $N$ Engl $f \mathrm{Med}$ 1987;317:850-5.

8 AIMS Trial Study Group. Effect of intravenous APSAC on mortality after acute myocardial infarction: preliminary report of a placebo-controlled clinical trial. Lance 1988;i:545-9.

9 ISIS 3. A randomised comparison of streptokinase versus tissue plasminogen activator versus anistreplase and of 
aspirin plus heparin versus aspirin alone among 41299 cases of suspected acute myocardial infarction. Lancet 1991;229:753-70.

10 Durrington PN, Ishola M, Hunt L, Arrol S, Bhatnagar D. Apolipoprotein (a), A1 and B and parental history in men with early onset ischaemic heart disease. Lancet 1988;i: $1070-3$.

11 Armstrong VW, Cremer P, Eberle E, Manke A, Schulz $\mathrm{EF}$, Wieland $\mathrm{H}$, et al. The association between serum nary atherosclerosis. Dependence on serum LDL levels. Atherosclerosis 1986;62:249-57.

12 Dahlen GH, Guyton JR, Altar MD, Farmer JA, Kautz JA, Gotto AM. Association of levels of lipoprotein $\operatorname{Lp}(\mathrm{a})$, potto AM. Association of levels of lipoprotein Lp(a), plasma lipids and other lipoproteins with coronary artery 74:758-65.

13 MacLean JW, Tomlinson JE, Kuang W-J, Eaton DL, Chen EY, Fless GM, et al. cDNA sequence of human apolipoprotein (a) is homologous to plasminogen. Nature 1987;300:132-7.

14 Hajjar KA, Gavish D, Breslow JL, Nachman RL. Lipoprotein (a) modulation of endothelial surface fibrinolysis and its potential role in atherosclerosis. Nature 1989;339:303-5.

15 Edelberg J, Pizzo SV. Why is lipoprotein (a) relevant to thrombosis. Am $\mathcal{f}$ Clin Nutr 1992;56:7915-25.

16 MBewu AD, Durrington PN, Bulleid S, Mackness MI. The immediate effect of streptokinase on serum lipoprotein (a) concentration and the effect of myocardial infarction on serum lipoprotein (a), apolipoprotein A; and $\mathrm{B}$, lipids and C-reactive protein. Atherosclerosis 1993;103:65-71.

17 Saran RK, Been M, Furniss SS, Hawkins T, Reid DS. Reduction in ST segment elevation after thrombolysis predicts either coronary reperfusion or preservation of predicts either coronary reperfusion or preservation
left ventricular function. $B r$ Heart $\mathcal{F} 1990 ; 64: 113-7$.

18 Hogg KJ, Hornung RS, Howie CA, Hockings N, Dunn FG, Hillis WS. Electrocardiographic prediction of coronary artery patency after thrombolytic treatment in acute nary artery patency after thrombolytic treatment in acute myocardial infarction; use of the ST segment
invasive marker. $B r$ Heart $₹ 1988 ; 60: 275-80$.

19 Willems JL, Willems RJ, Willems GT, Arnold AER, Van der Werf $F$, Verstraete $M$. For the European Cooperative Study Group for recombinant tissue type plasminogen activator. Significance of initial ST segment elevation and depression for the management of thrombolytic therapy in acute myocardial infarction. Circulation 1990;82:1147-58.

20 Selvester RH, Wagner JO, Rubin HB. Quantitation of myocardial infarction size and location by electrocardiogram and vector cardiogram. In: Snellin HA, ed. Boerhave course in quantitation in cardiology. The Netherlands: Leyden University Press, 1972:31-6.

21 Wagner GS, Freye CJ, Palmeri ST, Roark SF, Stack NC, Ideker RE, et al. Evaluation of a QRS scoring system for estimating myocardial infarct size. Circulation 1982;65: 242-50.

22 Mackness MI, Durrington PN. Lipoprotein separation and analysis for clinical studies. In: Converse CA, Skinner analysis for clinical studies. In: Converse CA, Skinner ER, eds. Lipoprotein analysis-a practical
Oxford: Oxford University Press, 1992:1-42.

23 MBewu AD, Bhatnagar D, Durrington PN, Hunt L, Ishola $M$, Arrol S, et al. Serum lipoprotein (a) in patients heterozygous for familial hypercholesterolaemia, their relatives and unrelated control populations. Arteriosclerosis 1991;11:940-6.
24 Srinivasan SR, Dahlen GH, Jarpa RA, Webber LS, Bevenson GJ. Racial (black white) differences in serum lipoprotein (a) distribution and its relation to parental myocardial infarction in children. Bogolusa heart study. Circulation 1991;84:160-7.

25 Seed M, Hopplicher MD, Reaveley D, McCarthy S, Thompson G, Boerwinkle E, Utermann G. Relation of serum lipoprotein (a) concentration and apolipoprotein (a) phenotype to coronary heart disease in patients with familial hypercholesterolaemia. $N$ Engl f Med 1990;322: 1494-9.

26 Rosengren A, Wilhelmsen L, Eriksson E, Risberg B, Wedel H. Lipoprotein (a) and coronary heart disease, a prospective case-control study in a general population prospective case-control study in a general population
sample of middle-aged men. BMF 1991;301:1248-51.

27 Jauhiainen M, Kastinen P, Ehnholm C, Frick MH, Manhtari M, Manninen V, Huttenen JK. Lipoprotein (a) and coronary heart disease risk: a nested case-control study of the Helsinki heart study participants. Atherosclerosis 1991;89:59-67.

28 Haffner SM, Moss SE, Klein BE, Klein R. Lack of association between lipoprotein (a) concentrations and coronary heart disease mortality in diabetes: the Wisconsin epidemiologic study of diabetic retinopathy. Metabolism 1992;41:194-7.

29 Maeda S, Abe A, Seishima M, Makino A, Noma A Kawade M. Transient changes of serum lipoprotein (a) as an acute phase protein. Atherosclerosis 1989;78: 145-50.

30 Gavish D, Azrolan N, Breslow JL. Plasma Lp(a) concentration is inversely correlated with the ratio of Kringle IV/Kringle $\mathrm{V}$ encoding domains in the apo (a) gene. Clin Invest 1989;184:2021-7.

31 Gonzalez-Gronow M, Edelberg JM, Pizzo SV. Further characterisation of the cellular plasminogen binding site. Evidence that plasminogen 2 and lipoprotein (a) comEvidence that plasminogen 2 and lipoprotein (a)
pete for the same site. Biochemistry 1989;28:2374-7.

pete for the same site. Biochemistry 1989;28:2374-7.
32 Harpel PC, Gordon BR, Parker TS. Plasmin catalyse binding of lipoprotein (a) to immobilized fibrinogen and binding of lipoprotein (a) to immobilized fibrinogen

33 Correc P, Kostner GM, Burtin P. A comparative study of the localisation of plasminogen and apolipoprotein (a) in human carcinomas. Thromb Res 1990;58:213-20.

34 Von Hodenberg E, Kreutzer J, Hautmann M, Mordt T, Kubler W, Bode C. Effects of lipoprotein (a) on success rates of thrombolytic therapy in acute myocardial infarction. Am ₹ Cardiol 1991;67:1349-53.

35 Armstrong VW, Neubauer C, Schutz E, Tebbe U. Lack of association between raised serum $\mathrm{Lp}$ (a) concentrations and unsuccessful thrombolysis after acute myocardia infarction. Lancet 1990;336:1077.

36 Tranchesi B, Filho RS, Vinagre C, Carmamelli B, Barbosa $\mathrm{V}$, Gebara V, et al. Lipoprotein levels do not influence the outcome of TPA therapy in acute myocardial infarction. Ann Haematol 1991;62:141-2.

37 Mao SJT, Tucci MA. Lipoprotein (a) enhances plasma clot lysis in vitro. FEBS Lett 1990;267:131-4.

38 Davies MJ. Successful and unsuccessful coronary thrombolysis. Br Heart $\mathcal{F}$ 1990;61:381-4.

39 Poole-Wilson PA, Iles RA. Ischaemia, hypoxia and reperfusion. In: Cohen RD, Lewis B, Alberti KGMM, Denman AM, eds. The metabolic and molecular basis of acquired disease. London: Baillere Tindall, 1990: of acquired

40 Braunwald E, Kloner RA. The stunned myocardium: prolonged postischaemic ventricular dysfunction Circulation 1982;66:1146-9. 